\title{
Analysis of Drying Kiln Aerodynamics Based on a Full Three-Dimensional Turbulent Numerical Computation
}

\section{Analiza aerodinamike sušionica na temelju trodimenzionalnoga turbulentnog numeričkog računanja}

\author{
Original scientific paper • Izvorni znanstveni rad \\ Received-prispjelo: 23. 2. 2015. \\ Accepted-prihvaćeno: 29. 1. 2016. \\ UDK: $630 * 847.24$ \\ doi:10.5552/drind.2016.1515
}

\begin{abstract}
This paper introduces a numerical methodology based on a 3D turbulent flow computation developed to assess the aerodynamic performances of lumber drying kilns. The numerical results are validated against experimental data obtained by applying five different fan speeds and reversible airflow. The distributions of the energy loss coefficient and of the non-uniformity flow coefficient were plotted along the flow path in both normal and reverse directions and the regions with larger air loss values were identified. The numerical computation revealed that three quarters of the airflow delivered by the fans bypasses the wood stacks through different gaps, consequently leading to a low aerodynamic efficiency (of 24-25\%) of the kiln.
\end{abstract}

Key words: drying kiln, airflow, Computational Fluid Dynamics, validation, aerodynamic efficiency

SAŽETAK • U radu je prezentirana numerička metodologija utemeljena na proračunima 3D turbulentnog protoka zraka, koja je razvijena kako bi se ocijenila aerodinamička izvedba sušionica za drvnu građu. Numerički su rezultati provjereni usporedbom s eksperimentalnim podacima dobivenim primjenom pet različitih brzina ventilatora i reverzibilnog protoka zraka. Raspodjele koeficijenta gubitka energije i koeficijenta neujednačenosti protoka prikazane su duž puta protoka u normalnome i obrnutom smjeru te su utvrđene regije u kojima su identificirane veće vrijednosti gubitka zraka. Numerički je proračun pokazao da tri četvrtine protoka ventilatorskog zraka zaobilaze složaje drva kroz različite praznine, što posljedično dovodi do niske aerodinamične učinkovitosti sušionica (od $24-25 \%)$.

Ključne riječi: sušionice, protok zraka, računalna dinamika fluida, provjera valjanosti, aerodinamična učinkovitost

\footnotetext{
${ }^{1}$ Authors are lecturer and professor at Faculty of Wood Engineering, Transilvania University of Brasov, Brasov, Romania. ${ }^{2}$ Author is senior researcher, Centre of Advanced Research in Engineering Sciences, Romanian Academy - Timisoara Branch, Timisoara, Romania.

${ }^{1}$ Autori su predavač i profesorica Faulteta drvne tehnologije, Transilvanijsko sveučilište u Brasovu, Brasov, Rumunjska. ${ }^{2}$ Autor je znanstvenik Centra za napredna istraživanja u tehničkim znanostima, Rumunjska akademija - Podružnica u Temišvaru, Temišvar, Rumunjska.
} 


\section{INTRODUCTION}

\section{UVOD}

Despite having been in use for over a century, conventional heat-and-vent drying kilns (Figure 1) are still in need of innovative solutions in order to improve their aerodynamic performances, which lead to better product quality and energy savings.

Most drying kilns allow for reversible airflow, in order to reduce moisture variation along flow path. Furthermore, the air inside the kiln is regulated to flow for a set time in one direction (further called, normal direction) and then for the same time in the opposite direction (further called, reverse direction). The normal direction (marked in Figure $1 \mathrm{~b}$ by continuous arrows) flows through the fan's outlet boundary $\rightarrow$ fan house $\rightarrow$ plenum chamber $\rightarrow$ stacks $\rightarrow$ plenum chamber $\rightarrow$ heating coils $\rightarrow$ fan house $\rightarrow$ fan's inlet boundary. The reverse direction (marked in Figure $1 \mathrm{~b}$ by dotted arrows) flows through the fan's outlet boundary $\rightarrow$ fan house $\rightarrow$ heating coils $\rightarrow$ plenum chamber $\rightarrow$ stacks $\rightarrow$ plenum $\rightarrow$ fan house $\rightarrow$ fan's inlet boundary.

The lumber boards are sticker-stacked to enhance kiln-drying by generating air channels between the boards. These channels are called sticker spaces or fillet spaces. When the stacks are placed inside the kiln, there are two large lateral spaces (plenum chambers) between the front door and the stacks and between the back wall and the stacks. Their function is to distribute the airflow evenly through the sticker spaces. Additionally, several further gaps (CPS, CPL, CPV and CPO) are generated around the stacks (Figure 1a).

Since these gaps have a lower aerodynamic resistance than the stacks, a part of the volumetric flow rate generated by the fans will bypass the lumber stacks. A bypass of 10-25\% normally occurs when a good kiln loading strategy is chosen (Langrish and Keey, 1996).

The airflow in lumber drying kilns has been studied since the 1930s by means of classical devices such as vane anemometers, hot-wire anemometers or pressure probes, but also by means of modern techniques like the Laser-Doppler anemometer (Ledig et al., 2007). In addition, numerical methods such as CFD (Computational Fluid Dynamics) are used to better understand and design drying equipment at lower costs than needed for experimental tests (Jamaleddine and Ray, 2010).

CFD has been used by several researchers to study the aerodynamics of lumber drying kilns or parts of it (Arnaud et al., 1991; Langrish and Keey, 1996; Salin and Ohman, 1998; Riepen and Paarhuis, 1999; Bian 2001; Hua et al., 2001; Sun, 2001; Bedelean and Sova, 2010). As a result, various solutions or recommendations have been formulated. Extensive reviews on different solutions and methodologies to improve the aerodynamic performances of lumber dryers have been published by Keey et al. (2000) and by Ledig et al. (2007).

Most of previous studies, that have analyzed the aerodynamics of drying kilns, have focused on the airflow either in front or inside the stacks, but not along the entire loop (i.e. fan's outlet boundary $\rightarrow$ fan house $\rightarrow$ plenum chamber $\rightarrow$ stacks $\rightarrow$ plenum chamber $\rightarrow$ heating coils $\rightarrow$ fan house $\rightarrow$ fan's inlet boundary). One possible reason is that the simultaneous interaction of all loop components upon the airflow behavior is very complex (Arnaud et al., 1991). In addition, there is a lack of numerical models in literature that are able to take into account all sources of airflow perturbations within the kiln (Ledig et al., 2001) such as: position of the fans, end-wall effects, separation zones, influence of the gaps around the stacks on the airflow bypass, etc.

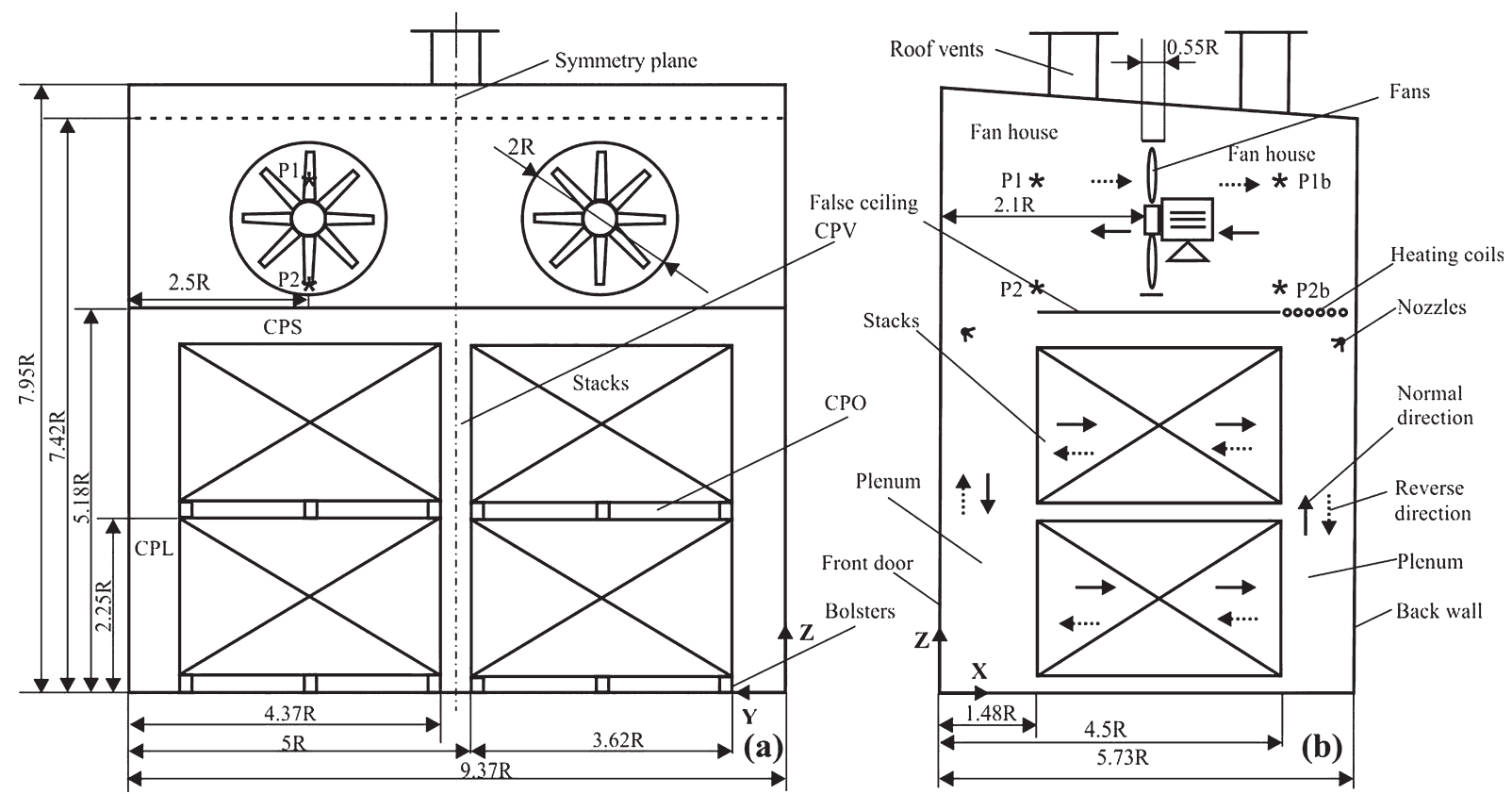

Figure 1 Laboratory kiln used in this study - frontal view (a) and side view (b): CPS - top gap; CPL - side gaps; $\mathrm{CPV}$ - vertical gap in-between stacks; CPO - horizontal gaps in-between stacks, $\mathrm{R}$ - fan radius

Slika 1. Laboratorijska sušionica: a) frontalni pogled, b) bočni pogled (CPS - prazni prostor na vrhu; CPL - bočne praznine; $\mathrm{CPV}$ - vertikalna praznina između složajeva; $\mathrm{CPO}$ - vodoravne praznine između složajeva, $\mathrm{R}$ - promjer ventilatora) 
This work introduces a novel methodology based on the fluid flow computation in 3D geometries, i.e. a lumber drying kiln. To demonstrate the applicability of the proposed methodology, the aerodynamics of a heatand-vent drying kiln (semi-scale model) was investigated in both normal and reverse airflow directions. In addition, the trapezoidal shape of the fan house (see Figure 1b) was taken into account. The methodology proposed in this paper paves the way towards a better analysis of the aerodynamics phenomena in order to improve the perfomances of lumber drying kilns.

\section{MATERIALS AND METHODS 2. MATERIJALI I METODE}

\subsection{Description of the drying kiln \\ 2.1. Opis sušionice}

The experiments were performed in a $4 \mathrm{~m}^{3}$ heatand-vent laboratory kiln, schematically presented in Figure 1. The kiln is equipped with two reversible overhead fans, a heating coil, two vents and two spray pipes, one on each side of the kiln. The fan speed can be adjusted from 0 to $1450 \mathrm{~min}^{-1}$ using an inverter and the power absorbed by each fan can be modified within the range of $0 \ldots 3000 \mathrm{~W}$. Consequently, the volumetric flow rate can be modified within the range of $0 \ldots 8.33$ $\mathrm{m}^{3} \cdot \mathrm{s}^{-1}$. The fan hub radius is $r=0.109 \mathrm{~m}$. The outer fan radius is $R=0.405 \mathrm{~m}$. This radius $(R)$ is further considered as the reference size; all other linear dimensions are related to it in order to obtain dimensionless sizes. Similarly, the annular section delimited by the two radii $\pi\left(R^{2}-r^{2}\right)$ will be considered as a reference for the transformation of areas into dimensionless sizes.

\subsection{Material and kiln setup}

2.2. Materijal i postavke sušionice

Four stacks were placed inside the kiln as a $2 \times 2$ matrix (Figure 1). Each stack contained eighty-eight sticker-stacked spruce (Picea abies) boards. Three stickers were placed in a row, at the ends and at half the length of the boards. Based on these input data, twenty $1200 \times 676 \times 24 \mathrm{~mm}$ sticker spaces arranged as a $2 \times 10$ matrix were generated in each stack. Three bolsters were placed below each stack (Figure 1a).

\subsection{Numerical setup}

\subsection{Numeričke postavke}

The 3D computational domain (Figure 2b) was created by dividing the small-scale experimental kiln by a symmetry plane at mid length (Figure $2 \mathrm{a}$ ). The governing equations (momentum and continuity) for the incompressible, steady and viscous flows are written as follows:

$\rho v_{\mathrm{i}} \frac{\partial v_{\mathrm{i}}}{\partial x_{\mathrm{i}}}=\rho g_{\mathrm{i}}-\frac{\partial p}{\partial x_{\mathrm{i}}}+\mu \frac{\partial^{2} v_{\mathrm{i}}}{\partial x_{\mathrm{i}}^{2}}$ and $\frac{\partial v_{i}}{\partial x_{i}}=0$

Where, $v$ is the velocity $\left(\mathrm{m} \cdot \mathrm{s}^{-1}\right), p$ is the pressure (Pa), $\rho$ is the air density $\left(\mathrm{kg} \cdot \mathrm{m}^{-3}\right), \mu$ is the dynamic air viscosity $(\mathrm{Pa} \cdot \mathrm{s})$, and $g$ is the gravitational acceleration $\left(\mathrm{m} \cdot \mathrm{s}^{-2}\right)$.

The inlet boundary of the 3D computational domain is the annular section between the outer fan diameter and the fan hub diameter. A uniform normal velocity corresponding to each volumetric flow rate value is imposed as the inflow condition, together with the turbulent quantities. A constant pressure on the annular outlet surface is imposed as the outflow boundary condition. The symmetry condition is imposed on the symmetry plane and the non-slip condition is imposed on all wall boundaries.

The Reynolds number corresponding to the airflow in the drying kiln ranges between $1.2 \times 10^{5}$ and $8.7 \times 10^{5}$. The Reynolds number is computed using the bulk velocity on the annular surface of the fan, the outer fan diameter and the kinematic air viscosity at $20^{\circ} \mathrm{C}$.

Turbulent flows with a high Reynolds number are difficult to model. Turbulence flows are greatly influenced by wall boundaries (Hinze, 1975), especially
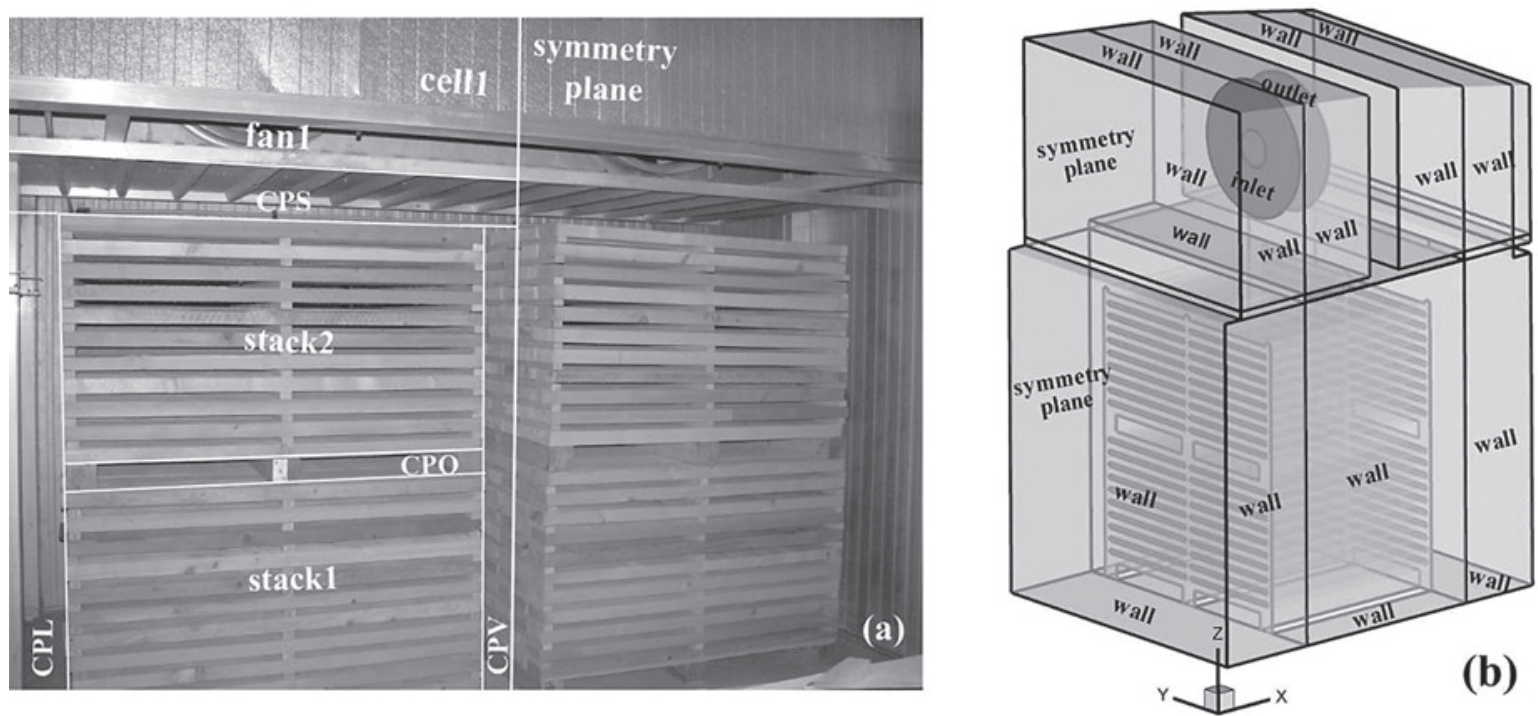

Figure 2 Computational domain of the drying kiln used in the numerical study: a - small-scale experimental kiln; b - threedimensional computational domain

Slika 2. Računalna domena sušionice koja je korištena u numeričkoj studiji: a) mala eksperimentalna sušionica; b) trodimenzionalna računalna domena 
when dealing with flows through relatively narrow channels. The viscosity affects the near-wall region, where the variables of the numerical solution change most rapidly. The non-equilibrium wall function approach is used to model this region. The wall function approach substantially saves computational resources for high Reynolds number flows, since it is economical, robust and reasonably accurate for the near-wall treatments (Craft et al., 2004). The near-wall treatment employs the non-equilibrium wall function for the turbulence model, with the potential benefit of better accounting for the adverse pressure gradients (Kim and Choudhury, 1995) in comparison to the standard wall functions.

Reynolds stress model (RSM) accounts for the effects of the streamline curvature, rotation, and rapid changes of the strain rate in a more rigorous manner than one-equation and two-equation models, and it is strongly recommended for highly anisotropic flows (Perot and Natu, 2004). In other words, the RSM accurately predicts complex flows. However, the fidelity of the RSM predictions is still limited by the closure assumptions employed to model various terms in the exact transport equations for the Reynolds stresses. The modeling of the pressure-strain and dissipationrate terms is particularly challenging, and is often considered responsible for compromising the accuracy of RSM predictions. The effects of strong turbulence anisotropy can only be rigorously modeled by applying the second-moment closure adopted in the RSM. The RSM closes the Reynolds-averaged Navier-Stokes equations by solving transport equations for the Reynolds stresses, together with an equation for the dissipation rate. The RSM involves the calculation of individual Reynolds stresses using differential transport equations. The individual Reynolds stresses are then used to obtain closure of the Reynolds-averaged momentum equation. Therefore, the RSM yields results that are clearly superior to the simpler models. This means that seven additional transport equations are solved in 3D flows. However, additional computational resources are required.

On the inlet section, one must specify the individual Reynolds stresses $v_{\mathrm{i}}^{\prime} v_{\mathrm{j}}^{\prime}$ and the turbulence dissipation rate $\varepsilon$. The turbulent kinetic energy $k=\overline{v_{\mathrm{i}}^{\prime} v_{\mathrm{j}}^{\prime}} / 2$ is ascertained by taking the trace of the Reynolds stress tensor. However, the turbulence intensity $T_{\mathrm{u}}(\%)$ expresses the "strength" of the turbulence motion being defined as the ratio of the root-mean-square of the velocity fluctuations $v^{\prime}\left(\mathrm{m} \cdot \mathrm{s}^{-1}\right)$, to the mean flow velocity $V\left(\mathrm{~m} \cdot \mathrm{s}^{-1}\right)$, according to Eq. (2):

$$
T_{\mathrm{u}}=\frac{1}{V} \sqrt{\frac{1}{3} \overline{v_{\mathrm{i}} v_{\mathrm{i}}^{\prime}}}
$$

Turbulence intensities of $7 \%$ and approximately $3 \%$ were measured by Fernandez Oro et al. (2008) in the rotor wakes of the axial fan and in the main stream, respectively. Therefore, an average value of $5 \%$ was selected on the annular inlet section of the drying kiln.

The second turbulent quantity corresponds to the characteristic length of the turbulence that has to be imposed on this section. This turbulent quantity char- acterizes the spatial dimension of the largest eddy of the turbulent structure. In our case, this length value was considered as $l=0.81 \mathrm{~m}$; equal to the outer diameter of the axial fan.

Three grids with hexahedral cells were generated using Gambit (Fluent Inc., 2006a) in order to assess the numerical solution with respect to the mesh refinement. As a result, the following structured meshes were considered in our procedure: a coarse grid (of approximately $1.2 \mathrm{M}$ cells), a medium grid (of approximately $2.1 \mathrm{M}$ cells) and a fine one (of approximately $2.6 \mathrm{M}$ cells).

The 3D turbulent steady computation was carried out using Fluent (Fluent Inc., 2006b) running in parallel. The incompressible flow equations were discretized using a finite volume method (FVM). The semiimplicit pressure linked equations (SIMPLE) algorithm for pressure-velocity coupling was selected for the numerical investigation. The convection terms are discretized using a $2^{\text {nd }}$ order upwind scheme in both momentum and turbulence equations and a PRESTO scheme for pressure. The parallelization was obtained by a domain decomposition procedure. The communication time was minimized by employing the METIS graph partitioning procedure (Karypis and Kumar, 1998).

\subsection{Experimental method \\ 2.4. Eksperimentalna metoda}

It was necessary to disassemble the heating coils in order to capture the flow features, particularly since this study focused on the aerodynamics of a drying kiln. The same strategy was applied by several researchers (Arnaud et al.,1991; Bian, 2001; Hua et al., 2001 ) in order to numerically investigate the airflow inside a lumber drying kiln. In particular, the pressure drop on the heating coils and other kiln elements (bends, baffles) is less than that of the lumber stacks (Perre and Keey, 2006).

The static pressure and air velocity were measured at two different positions (P1 and P2, see Figure 1b), in both air stream directions (normal and reverse). The measurements were done for five fan speeds, namely $1450,1250,1000,750$ and $500 \mathrm{~min}^{-1}$. The fan speed was strictly controlled by a frequency inverter. The measurements were performed both in descending $\left(1450 \ldots 500 \mathrm{~min}^{-1}\right)$ and ascending order $(500 \ldots 1450$ $\left.\min ^{-1}\right)$ to determine the experimental error. The kiln doors and vents were closed during the measurements.

At each point of interest, the static pressure and air velocity were recorded for 10 minutes, for each investigated fan speed; as a result, around 400 data were recorded for both static pressure and air velocity during this time. The static pressure was measured using a differential pressure sensor FD A602 - S1K with an accuracy of $\pm 0.5 \%$, provided by Ahlborn. The static pressure probes with a diameter of $0.006 \mathrm{~m}$ were connected to the pressure sensor by means of two silicone hoses. The air velocity was measured using a rotating vane air velocity sensor FVA915S220, which was also delivered by Ahlborn, with an $11 \mathrm{~mm}$ measuring head diameter and an accuracy of $\pm 3 \%$. Both sensors were connected to a data-logger Almemo 2590 - 4S. The 

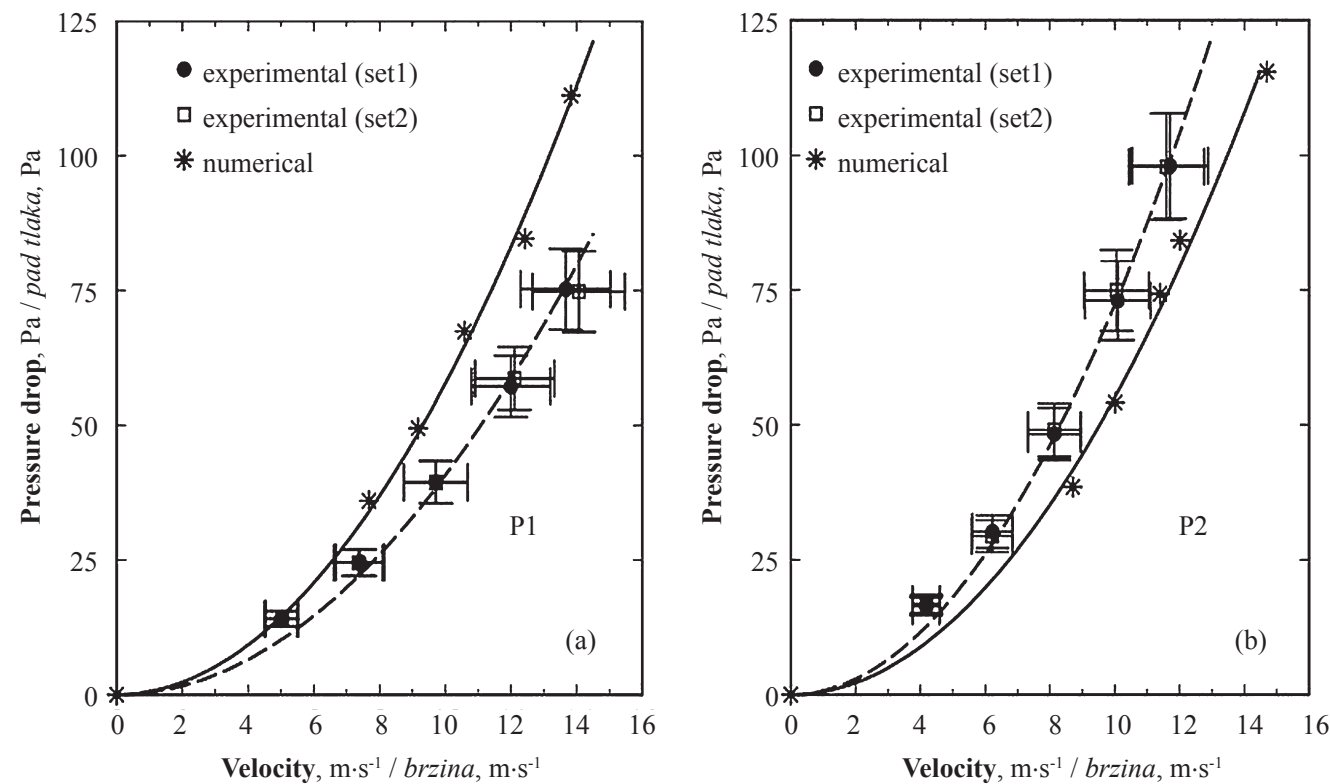

Figure 3 Validation of numerical results against experimental data measured in normal air flow direction at measuring points P1 (a) and P2 (b)

Slika 3. Provjera valjanosti numeričkih rezultata na temelju eksperimentalno dobivenih podataka pri normalnom smjeru protoka zraka na mjernim mjestima P1 (a) i P2 (b)

data were simultaneously recorded through different input channels. The AMR Control Software V.5.15 was used to acquire and transfer the data from the data-logger to a laptop computer.

\subsection{Model validation}

\subsection{Provjera valjanosti modela}

The numerical results are validated against the experimental data obtained in both directions of airflow. First, the measuring positions P1 and P2 located in the fan house are considered, see Figure 1. Figures 3 and 4 plot the pressure drop against the air velocity in both flow directions at these two points. A reasonable agreement between the numerical results (marked with stars) and the experimental data in the normal direction

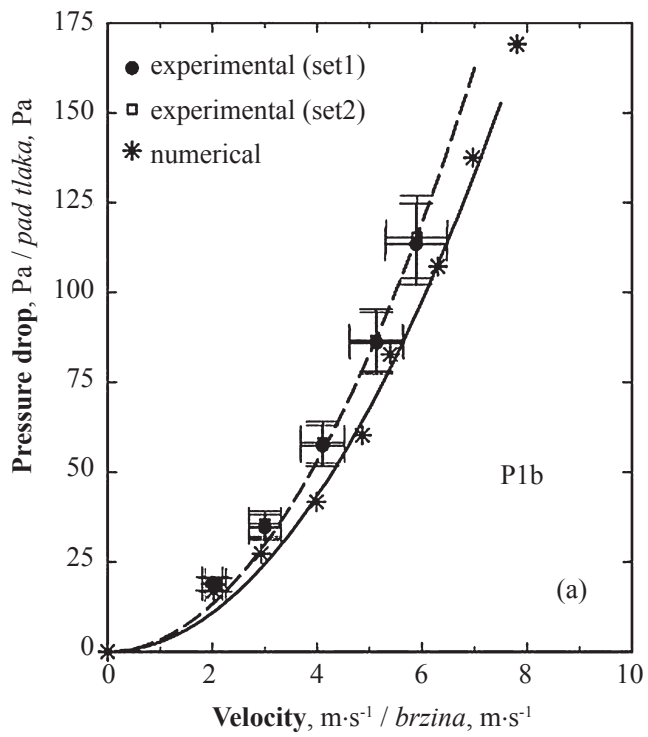

of the airflow was obtained (Figure 3). However, better agreement can be observed in the reverse direction of airflow (Figure 4). When comparing the results obtained in these two measuring locations (P1 and P2), a better validation of the numerical results against the experimental data is revealed at location $\mathrm{P} 2$, positioned near the false ceiling.

\subsection{Numerical methodology for aerodynamic analysis of the drying kiln}

2.6. Numerička metodologija za aerodinamičku analizu sušionice

When experimentally investigating the flow in a drying kiln, usually the average pressure is measured at the fan inlet and outlet. In addition, the loss coefficient

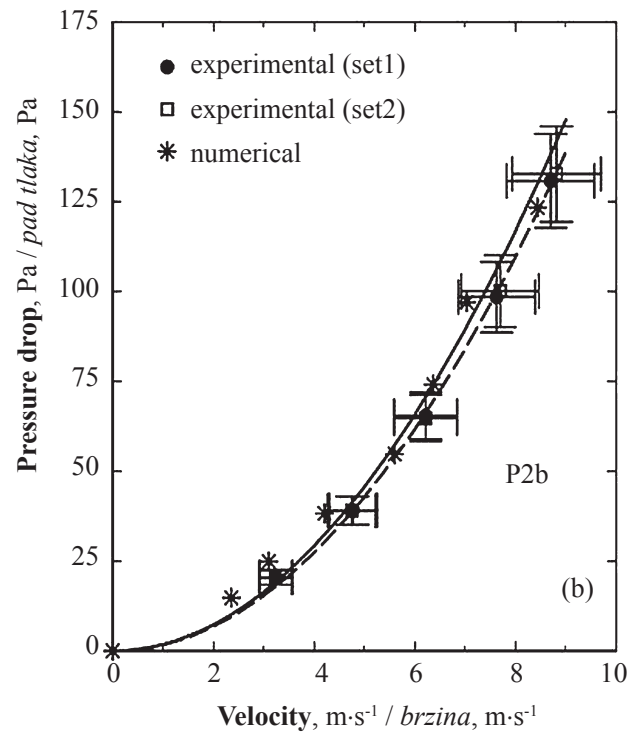

Figure 4 Validation of numerical results against experimental data measured in reverse air flow direction at measuring points P1 (a) and P2 (b)

Slika 4. Provjera valjanosti numeričkih rezultata na temelju eksperimentalno dobivenih podataka pri obrnutom smjeru protoka zraka na mjernim mjestima P1 (a) i P2 (b) 
is defined using the average air velocity, computed as the volumetric flow rate divided by the corresponding cross-section area. However, this rather simple approach, inspired from basic aerodynamics, does not provide meaningful results, especially when the flow is highly non-uniform, with large recirculation regions.

On the other hand, when a full 3D flow computation is performed on the drying kiln, both velocity and pressure fields are assessable in several sections, and a more rigorous approach can be employed to assess the flow within the control volume bounded by the closed surface consisting of the inlet section, outlet section and kiln walls, as shown in Figure $2 b$. When computing incompressible flows, the static pressure is defined up to an arbitrary constant. As a result, only pressure difference representations make sense. On the other hand, the dynamic pressure is relevant as an absolute value, since the lack of dynamic pressure clearly corresponds to flow stagnation.

Therefore, integral quantities are defined in order to compute the relevant parameters associated to the drying kiln aerodynamics. In order to analyze the energy transformation process, as well as its efficiency, the following integral quantities on a generic cross section $S$ were introduced (Susan-Resiga et al., 2010):

$$
\begin{gathered}
\Pi(S) \equiv \int_{\mathrm{S}} p_{\mathrm{p}} \cdot v_{n} d S \\
K(S) \equiv \int_{\mathrm{S}} \frac{\rho \cdot v^{2}}{2} v_{n} d S \\
W(S) \equiv \Pi(S)+K(S)
\end{gathered}
$$

Where, $\Pi$ is the flux of the potential energy (W), $K$ is the flux of the kinetic energy (W) and $W$ is the flux of the mechanical energy (W) and $v_{n}$ is the normal component of the velocity on the surface $S$.

In numerical computations, the static pressure is actually the piezometric pressure $p_{\mathrm{p}}=p+\rho g z$. For a control volume of the drying kiln, bounded by the closed surface previously described, the net flux of the specific mechanical energy is

$$
W=W_{\text {IN }}-W_{\text {OUT }}
$$

For viscous flows, the viscous friction converts part of the mechanical energy into heat yield $(W>0)$. This energy flux imbalance is associated with the aerodynamic losses. As a result, $W(S)$ decreases monotonically from the inlet to the outlet of the drying kiln. In the present analysis, the authors considered only steady flows. Therefore, it is correct to consider the specific energy flux as defined by Eq. (6).

The total aerodynamic power, that has dissipated up to section $S$, is $W(S)-W_{\text {out }}>0$, where $W_{\text {out }}=\Pi_{\text {out }}+$ $K_{\text {out }}$ with $W_{\text {out }}=W\left(S_{\text {out }}\right), \Pi_{\text {out }} \stackrel{\text { out }}{=} \Pi\left(S_{\text {out }}\right)$ and $K_{\text {out }}=K\left(S_{\text {out }}{ }_{\text {out }}\right)$, corresponding to the integral quantities on the annular outlet section.

The energy loss coefficient is usually defined as

$$
\zeta(S) \equiv \frac{W(S)-W_{\text {out }}}{K_{\text {out }}}=\frac{\Pi(S)-\Pi_{\text {out }}}{K_{\text {out }}}-\left(1-\frac{K(S)}{K_{\text {out }}}\right)
$$

The first term in Eq. (7) corresponds to what is called the potential energy coefficient

$$
c_{\Pi}(S) \equiv \frac{\Pi(S)-\Pi_{\text {out }}}{K_{\text {out }}}
$$

while the second term in Eq. (7) corresponds to the so-called kinetic energy coefficient

$$
c_{\mathrm{K}}(S) \equiv 1-\frac{K(S)}{K_{\text {out }}}
$$

The variance in kinetic energy within the drying kiln should also be considered. The flux of specific kinetic energy is computed according to Eq. (4). On the other hand, for an ideal flow with constant average volumetric flow rate (normal) velocity on each crosssection, the flux of specific kinetic energy would be $K^{\text {ideal }}(S)$, defined by the following equation:

$$
K^{\text {ideal }}(S)=Q \cdot \frac{\rho}{2} \cdot\left(\frac{Q}{S}\right)^{2}
$$

This is the reference baseline, and $K(S)$ will always have higher values. Consequently, the airflow non-uniformity can be quantified through the coefficient

$$
\xi(S) \equiv \frac{K(S)}{K^{\text {ideal }}(S)}
$$

Besides the non-uniformity coefficient $\xi(S)$, the kinetic energy excess is also relevant for the analysis of the drying kiln aerodynamics.

In practice, the pressure drop is usually examined instead of the aerodynamic power loss. The corresponding pressure loss for the kiln control volume is defined by the equation:

$$
W=\Delta p \cdot Q
$$

Where, $\Delta p$ is the total pressure drop in the kiln (Pa) and $Q$ is the volumetric flow rate $\left(\mathrm{m}^{3} \cdot \mathrm{s}^{-1}\right)$ computed according to the following equation:

$$
Q(S) \equiv \int_{\mathrm{S}} v_{n} d S
$$

Where, $v_{n}\left(\mathrm{~m} \cdot \mathrm{s}^{-1}\right)$ is the normal component of the velocity on the surface $S$.

The following flow-related quantities associated with kiln drying are written in dimensionless form:

$$
\begin{gathered}
w=\frac{W}{\frac{1}{2} \cdot \rho \cdot v_{\text {ref }}^{2} A_{\text {ref }}} \\
k=\frac{\Delta p}{\frac{1}{2} \cdot \rho \cdot v_{\text {ref }}^{2}} \\
q=\frac{Q}{v_{\text {ref }} \cdot A_{\text {ref }}}
\end{gathered}
$$

Where, $w$ is the dimensionless aerodynamic power loss, $k$ is the dimensionless pressure loss, $q$ is the dimensionless volumetric flow rate, $A_{\text {ref }}$ is the reference area $\left(\mathrm{m}^{2}\right)$ associated to the annular inlet section and $v_{\text {ref }}$ is the reference velocity $\left(\mathrm{m} \cdot \mathrm{s}^{-1}\right)$ corresponding to the bulk velocity through the reference section.

Since the tested kiln had gaps around the stacks, the volumetric flow rate generated by the fan $(Q)$ can 
be conveniently divided into two parts: one part goes through the stacks $\left(Q_{1}\right)$ and the other goes around the stacks $\left(Q_{2}\right)$ via the gaps. The bypass coefficient $(b)$ in Eq. (21) is defined, according to Nijdam and Keey (1996), as a ratio between the two flow rates:

$$
b=\frac{Q_{2}}{Q_{1}}
$$

The aerodynamic efficiency of the kiln can be defined either as a ratio between the volumetric flow rate through the stacks $\left(Q_{1}\right)$ and the total volumetric flow rate delivered by the fan $(Q)$ or by means of the bypass coefficient, according to Eq. (18):

$$
\eta=\frac{Q_{1}}{Q}=\frac{1}{(1+b)}
$$

\section{RESULTS AND DISCUSION}

\section{REZULTATI I RASPRAVA}

\subsection{Aerodynamic analysis of drying kiln}

3.1. Aerodinamična analiza sušionice

The numerical simulations for turbulent flow in the drying kiln were performed in both airflow directions, for five fan speeds, as detailed in the experimental approach.

The cross-sections $S$ of the kiln geometry, defined for the numerical analysis, are marked with grey shadows in Figure 5a. The thick black line represents the mid-line, which connects the successive centers (bold black bullets) of these cross-sections.

From the geometrical point of view, the airflow in the drying kiln is suddenly modified when the flow direction and/or the shape of the cross section changes along the kiln's mid-line, as shown in Figure 5b.

The cross-section area is expressed as a dimensionless size by relating it to the annular fan section, while the mid-line length is expressed as a dimensionless size by relating it to the outer fan radius. In our case, it can be observed that the mid-line length of the drying kiln is about fourteen times longer than the reference radius. It is important to mention that the lumber stacks are located approximately at mid length of the kiln's mid-line. Figure 5b shows a region with constant area distribution associated to the stacks and several sudden expansions/contractions of the cross-section area along the aerodynamic passage.

However, only one distribution is associated to each airflow direction using the dimensionless sizes. As a result, the distribution of the potential energy coefficient $c_{\Pi}$ defined according to Eq. (8) is plotted against the dimensionless length of the kiln's mid-line, as illustrated in Figure 6a. The overall potential energy drop is the same in both airflow directions (normal and reverse). The potential energy drop from the annular inlet section to the stack is smaller than the value determined from the stack up to the outlet section in both airflow directions. The most significant variation of the potential energy coefficient is observed in the fan house located in front of the outlet section.

The kinetic energy coefficient $c_{\mathrm{K}}$, expressed according to Eq. (9), is plotted versus the dimensionless length of the kiln's mid-line in Figure 6b. The overall kinetic energy difference, defined between the inlet and outlet sections of the drying kiln, is the same in both airflow directions (normal and reverse). In spite of this, the $c_{\mathrm{K}}$ distribution along the kiln's mid-line significantly differs between the normal and reverse direction of the airflow. A greater decrease is obtained up to the cross-section defined at the stack inlet in the normal flow direction compared to the reverse direction. This discrepancy includes the cross-section area variation from the annular fan inlet section to the stack inlet sec-

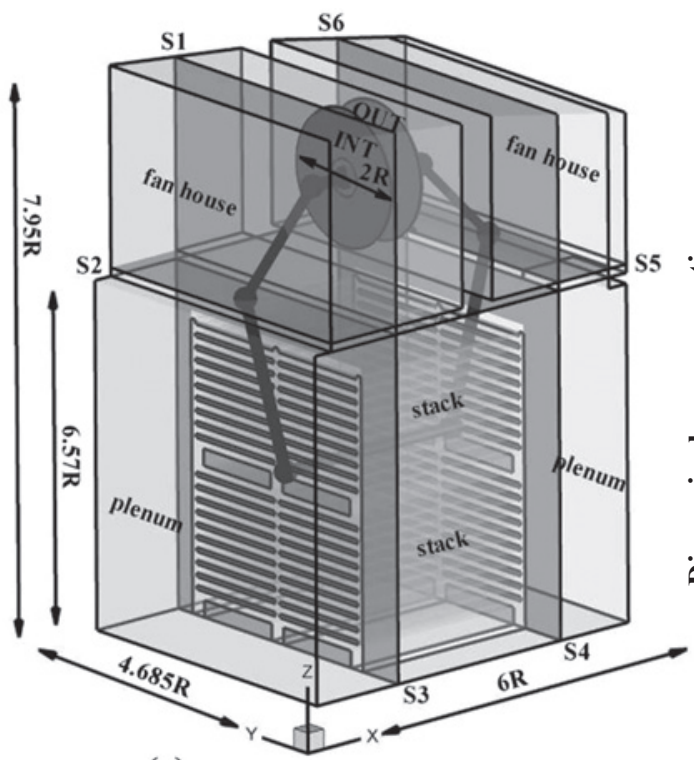

(a)

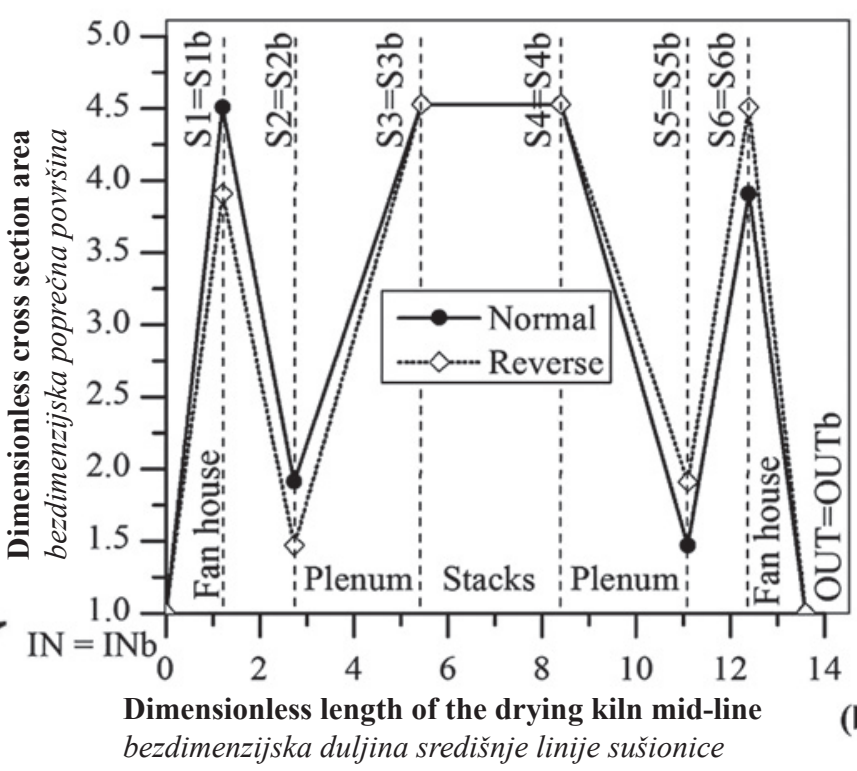

(b)

Figure 5 Kiln cross-sections (S1...S6) defined for the numerical analysis (a) and dimensionless cross-section area distribution vs. dimensionless length of the kiln mid-line (b) in $\bullet$ normal and $\diamond$ reverse air flow direction

Slika 5. a) Poprečni presjeci sušionice (S1 ...S6) određeni za numeričku analizu; b) raspodjela bezdimenzijske površine poprečnog presjeka sušionice u odnosu prema bezdimenzijskoj duljini središnje linije sušionice pri normalnome $(\bullet)$ i obrnutom $(\diamond)$ smjeru protoka zraka 


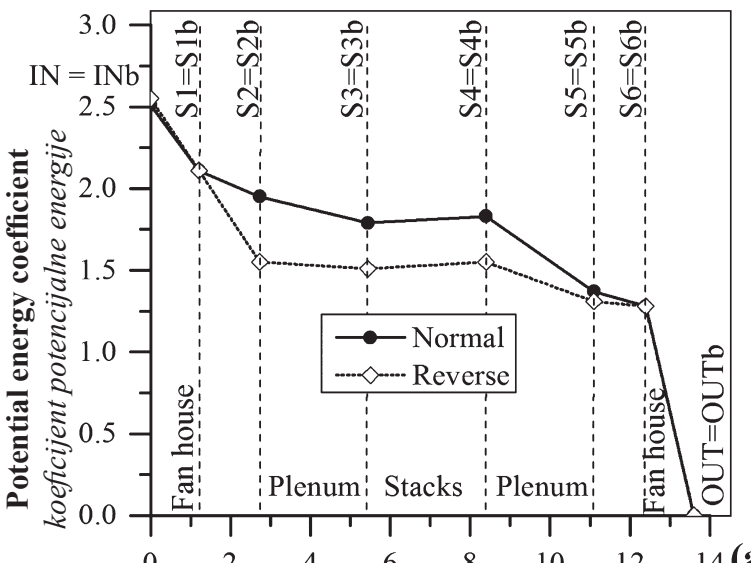

$\begin{array}{lll}10 & 12 & 14\end{array}$ (a)

Dimensionless length of the drying kiln mid-line

bezdimenzijska duljina središnje linije sušionice

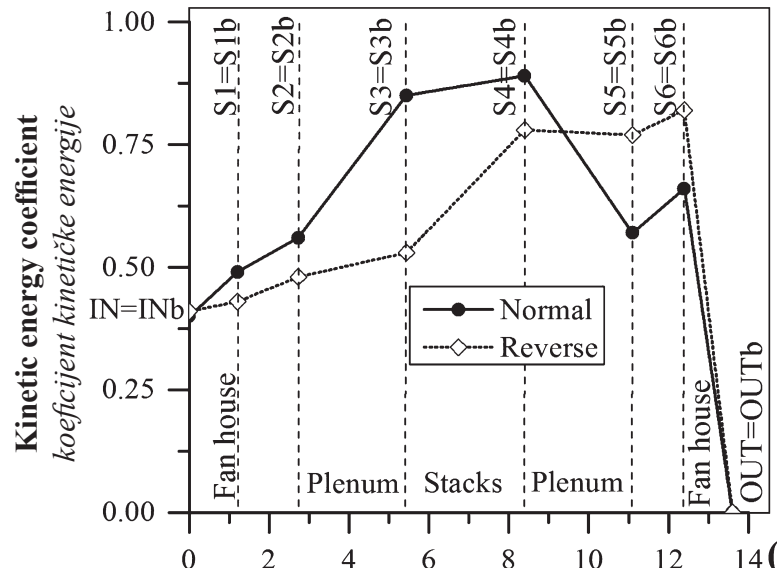

Dimensionless length of the drying kiln mid-line bezdimenzijska duljina središnje linije sušionice

Figure 6 Distribution of potential (a) and kinetic energy (b) coefficient versus the dimensionless length of the kiln mid-line, in $\bullet$ normal and $\diamond$ reverse air flow direction

Slika 6. Raspodjela koeficijenta potencijalne (a) i kinetičke energije (b) u odnosu prema bezdimenzijskoj duljini središnje linije sušionice pri normalnome $(\bullet)$ i obrnutom $(\diamond)$ smjeru protoka zraka

tion in both directions. A significant difference in the variation and values of the $c_{\mathrm{K}}$ in both directions is also revealed in the stacks. This difference is clearly generated by the aerodynamic conditions, because the crosssectional area of the stack is considered constant from the point of the air inlet until the air outlet. In the last fan house, the kinetic energy increases again, due to the significant decrease of the cross-sectional area.

The energy loss coefficient $\zeta$ determined along the kiln's mid-line, as defined according to Eq. (7), is represented in Figure 7a. The overall energy loss coefficient between the inlet and outlet sections of the drying kiln is about 2.0 in both airflow directions. However, the energy loss coefficient distribution along the kiln's mid-line is different to that in the opposite airflow direction. The value of the energy loss coefficient is practically the same for the stack inlet cross-section
( $S 3$ in the normal air direction and $S 3 b$ in the reverse direction). This value is roughly half of the overall energy loss.

A monotonic decrease of the energy loss coefficient from the inlet to the outlet is revealed in both airflow directions. In the normal direction, the energy loss coefficient decreases up to the stack inlet cross-section, then it becomes negligible along the stacks and it decreases again, but considerably less, in the plenum and in the fan house. A significant difference observed in the reverse direction is contributable to the stacks region, where the energy loss coefficient is no longer constant, but instead decreases by approximately $10 \%$ and is due to the distribution of the kinetic energy component, as depicted in Figure $6 \mathrm{~b}$.

The non-uniformity coefficient $\xi$ defined according to Eq. (11) is illustrated along the kiln's mid-line in
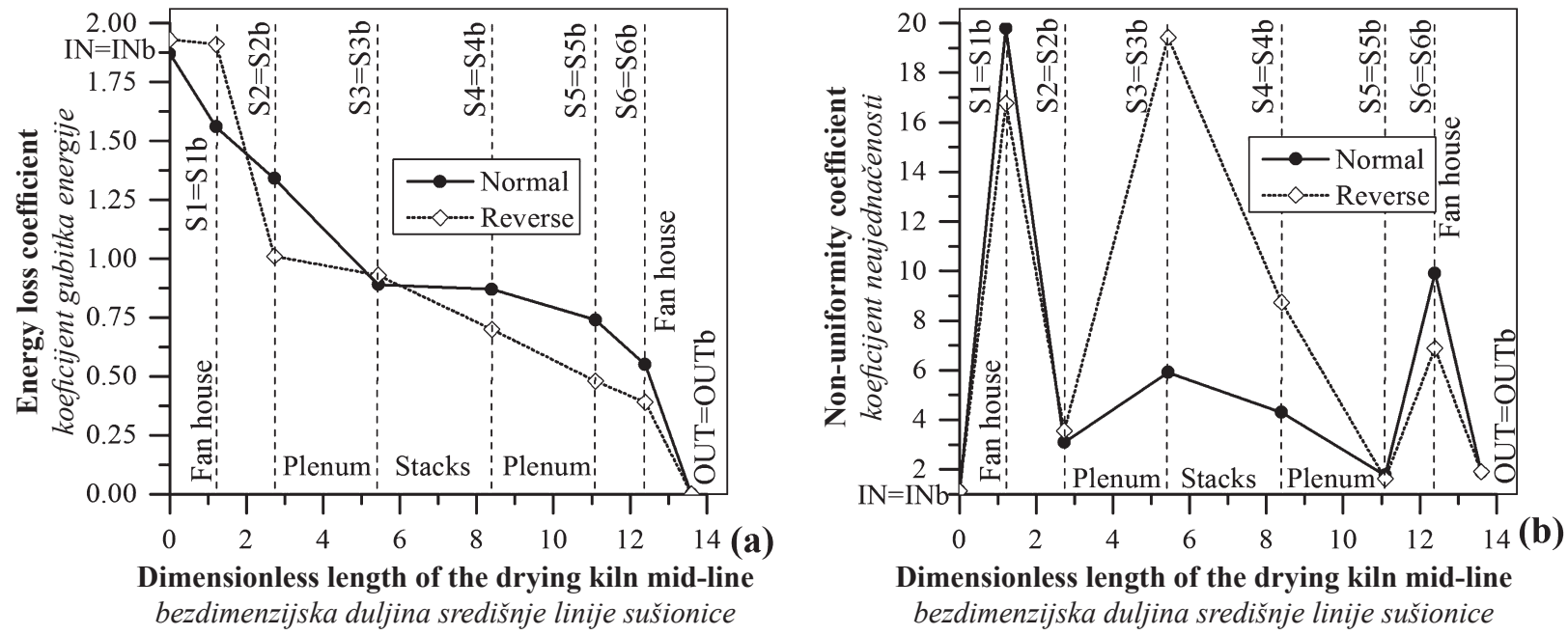

Figure 7 Distribution of energy loss (a) and non-uniformity (b) coefficient versus dimensionless length of the kiln mid-line in - normal and $\diamond$ reverse air flow direction

Slika 7. Raspodjela gubitka energije (a) i koeficijenta neujednačenosti (b) u odnosu prema bezdimenzijskoj duljini središnje linije sušionice pri normalnome $(\bullet)$ i obrnutom $(\diamond)$ smjeru protoka zraka 
Table 1 Overall dimensionless quantities associated to the given kiln configuration in both (normal and reverse) air flow directions

Tablica 1. Ukupne bezdimenzijske vrijednosti povezane s konfiguracijom sušionice u oba smjera protoka zraka (normalnome i obrnutome)

\begin{tabular}{|c|c|c|c|c|c|}
\hline \multicolumn{2}{|c|}{$\begin{array}{c}\text { Dimensionless volumetric } \\
\text { flow rate }(\boldsymbol{q}) \\
\text { Bezdimenzijski volumni protok }\end{array}$} & \multicolumn{2}{|c|}{$\begin{array}{c}\text { Dimensionless aerodynamic } \\
\text { power loss }(\boldsymbol{w}) \\
\text { Bezdimenzijski aerodinamički gubitak } \\
\text { snage }\end{array}$} & \multicolumn{2}{|c|}{$\begin{array}{c}\text { Dimensionless } \\
\text { pressure loss }(\boldsymbol{k}) \\
\text { Bezdimenzijski gubitak tlaka }\end{array}$} \\
\hline $\begin{array}{c}\text { Normal } \\
\text { Normalni smjer }\end{array}$ & $\begin{array}{c}\text { Reverse } \\
\text { Obrnuti smjer }\end{array}$ & $\begin{array}{c}\text { Normal } \\
\text { Normalni smjer }\end{array}$ & $\begin{array}{c}\text { Reverse } \\
\text { Obrnuti smjer }\end{array}$ & $\begin{array}{c}\text { Normal } \\
\text { Normalni smjer }\end{array}$ & $\begin{array}{c}\text { Reverse } \\
\text { Obrnuti smjer }\end{array}$ \\
\hline \multicolumn{2}{|c|}{1.21} & $5.14 \pm 0.08$ & $5.4 \pm 0.11$ & $2.83 \pm 0.05$ & $2.91 \pm 0.09$ \\
\hline
\end{tabular}

Figure $7 \mathrm{~b}$. This parameter is computed relative to the ideal value on each cross section, in order to avoid the influence of a variable flow area.

The unit value of this coefficient indicates a uniform distribution of the flow over the cross section. In contrast, larger values suggest a non-uniform flow compared to the ideal case. The non-uniformity coefficient distributions in both airflow directions reveal larger values. Thus, a greater degree of non-uniformity is observed in the fan house located in front of the inlet section. Naturally, the air jet delivered by the fan in the house leads to greater non-uniformity of the flow, which is in agreement with the numerical results. Moreover, the value in the normal flow direction is larger than the value in the reverse direction, due to the differences in the fan house geometry. Figure 1 shows that the fan house geometry is divergent in the normal flow direction, inducing thus large recirculation regions. However, the recirculation regions are smaller in the reverse flow direction due to the convergent fan house geometry.

The values of the non-uniformity coefficient $\xi$ on the stack inlet and outlet cross-sections are 2 to 4 times larger in the reverse airflow direction than in the normal direction.

The overall dimensionless quantities associated with this configuration of the drying kiln, analyzed in both normal and reverse airflow directions, are given in Table 1 . These overall values concerning aerodynamic parameters are useful in the design of axial fans for lumber drying kilns.

\subsection{Bypass analysis}

3.2. Analiza zaobilaženja

Considering the volumetric flow rate generated by the fan $(Q)$, only $24 \%$ in the normal direction and $25 \%$ in the reverse direction pass through the sticker spaces $\left(Q_{1}\right)$. The other part $\left(Q_{2}\right)$ bypasses the stacks. This small percentage of volumetric flow rate that goes through the sticker spaces is due to the fact that the area of gaps around the stacks is about 1.15 times larger than that of the sticker spaces and, also, due to the fact that their aerodynamic resistance is smaller than that opposed by the stacks.

The bypass coefficient computed using Eq. (17) reveals that the volumetric flow rate that bypasses the stacks $\left(Q_{2}\right)$, also called "air leakage", is about three times larger than the air quantity that goes through the sticker spaces $\left(Q_{1}\right)$ in both air directions: the bypass coefficient is 3.15 for the normal airflow direction and 3.04 in the reverse direction. Therefore, the aerody- namic efficiency values of the tested kiln are, according to Eq. (18), 0.24 and 0.25 , respectively, in the normal and reverse directions. These are very low values and they apply when the kiln is loaded at full capacity. When the kiln is partially loaded, the aerodynamic efficiency value is further reduced. This happens due to the increasing ratio between the aerodynamic resistance associated to the stack region and the aerodynamic resistance of the gaps around the stacks. Therefore, the drying kiln has to be equipped with baffles in order to overcome both negative effects of the air bypass upon the drying time and the drying uniformity (Riley, 2006; Bedelean and Sova, 2012).

The influence of the airflow direction upon the air losses recorded in each gap around the stacks at the inlet section $(S 3 / S 3 b)$ is illustrated in Figure 8. The graph shows that the air leakage through the top gap (CPS) is $15 \%$ higher in the reverse direction than in the normal direction. As a result, the reverse flow direction favors the drying of the first row of boards located in the upper stack. On the other hand, the air loss in the side gap (CPL) is approximately $13 \%$ higher in the normal direction. The air loss in the vertical gap (CPV), however, is not as strongly influenced by the airflow direction, being only slightly (by $2 \%$ ) higher in the normal direction (Figure 8).

The air leakage balance between the inlet and outlet section is analyzed in Figure 9 in each airflow

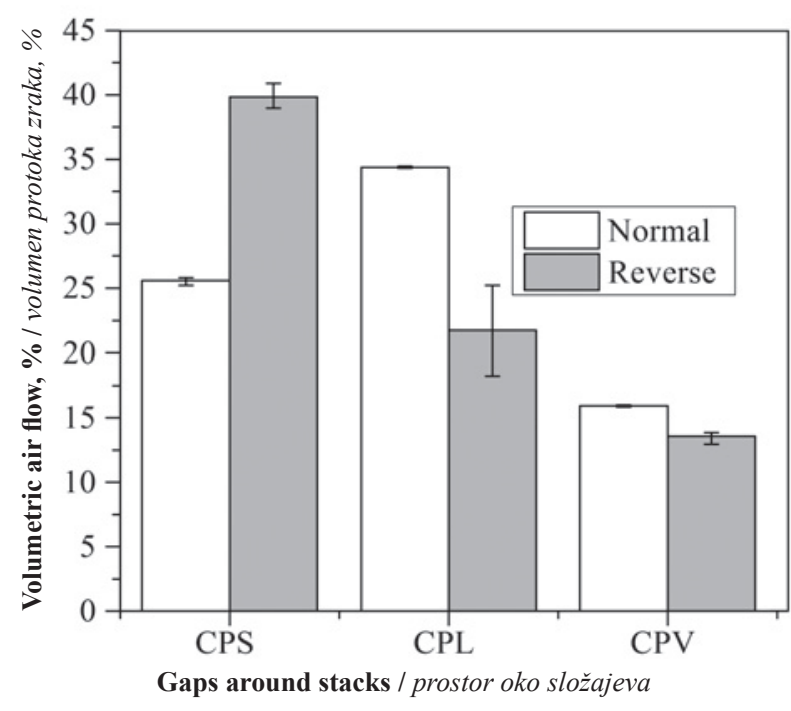

Figure 8 Distribution of air leakage $\left(Q_{2}\right)$ on the stack inlet section in both flow directions

Slika 8. Raspodjela količine zraka koja pri oba smjera protoka zaobilazi složaj $\left(Q_{2}\right)$ na njegovu ulaznom dijelu 

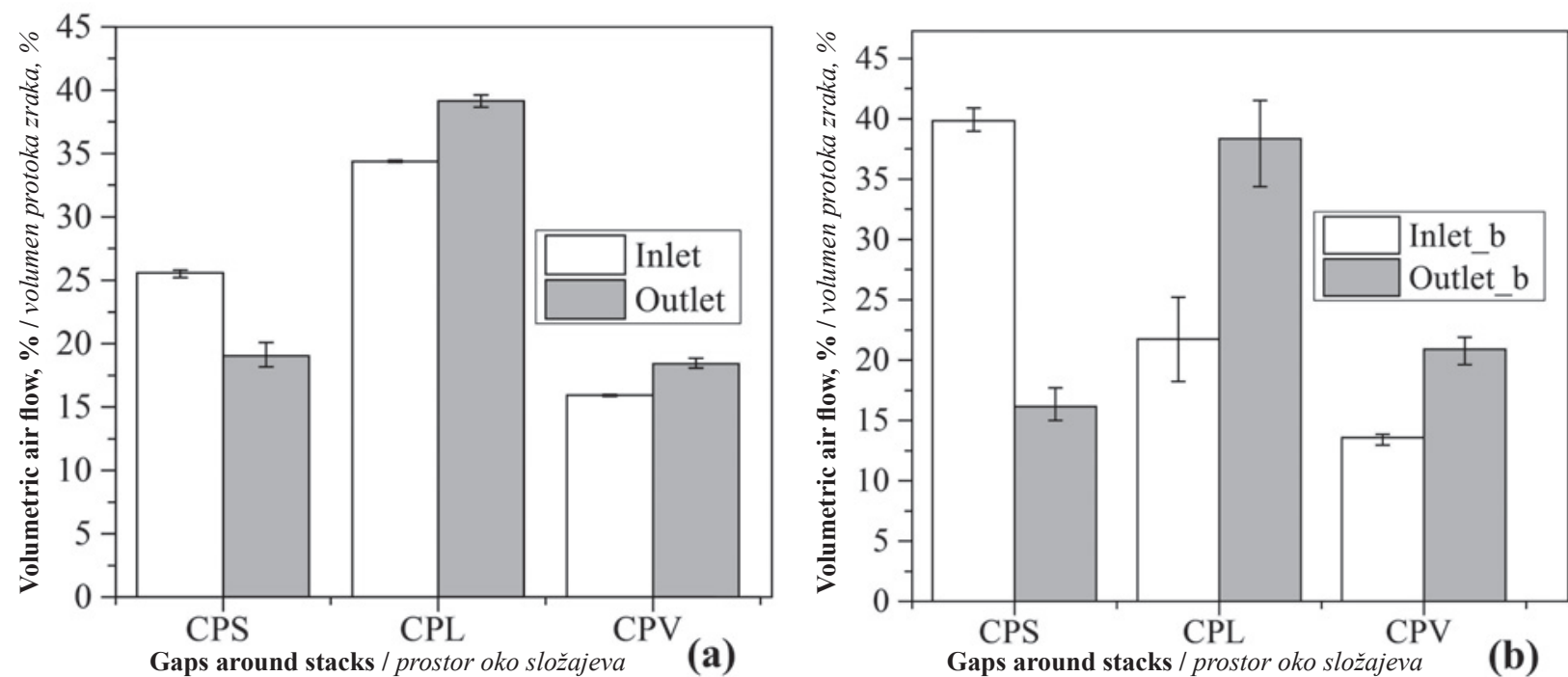

Figure 9 Distribution of air leakage on both the inlet (S3 and S3b) and outlet section (S4 and S4b) of the stacks in normal and reverse flow direction

Slika 9. Raspodjela količine zraka koja pri oba smjera protoka zaobilazi složaj na njegovu ulaznom (S3 i S3b) i izlaznom dijelu (S4 i S4b)

direction, in order to better understand the aerodynamics of the drying kiln.

A moderate air leakage balance (within a $7 \%$ limit) is obtained in the normal flow direction between the inlet (S3) and outlet section (S4). In this case, air leakage through the top gap (CPS) of the outlet surface is redistributed towards the side gap (CPL) by $5 \%$ and the vertical gap (CPV) by $2 \%$.

In the reverse direction, a significant redistribution of the air leakage between the inlet $(S 3 b)$ and outlet sections $(S 4 b)$ takes place. The air leakage through the top gap (CPS) ranges between $40 \%$ (at the inlet) and $16 \%$ (at the outlet), which means a difference of $24 \%$ (Figure $9 b$ ). This value is 3.5 times greater than the air leakage in the normal flow direction. Correspondingly, $14 \%$ and $10 \%$ of the air leakage through the top gap (CPS) on the outlet surface is redistributed towards the side gap (CPL) and the vertical gap (CPV), respectively. The redistribution of the air losses along the flow path from the inlet towards the outlet section of the stacks is due to the pressure distribution in the outlet plenum of the drying kiln.

The convergent study is performed in order to assess the numerical solution accuracy. The bypass coefficient $(b)$ and the aerodynamic efficiency $(\eta)$ are computed on different grids. As a result, the relative error

Table 2 Numerical results determined by convergence study Tablica 2. Numerički rezultati dobiveni konvergentnom analizom

\begin{tabular}{|c|c|c|c|}
\hline \multirow{2}{*}{$\begin{array}{c}\text { Quantity / } \\
\text { Veličina }\end{array}$} & \multicolumn{3}{|c|}{ Grid type / Vrsta mreže } \\
\cline { 2 - 4 } & $\begin{array}{c}\text { Coarse } \\
\text { Gruba }\end{array}$ & $\begin{array}{c}\text { Medium } \\
\text { Prosječna }\end{array}$ & $\begin{array}{c}\text { Fine } \\
\text { Fina }\end{array}$ \\
\hline$b$ & 3.06 & 3.15 & 3.26 \\
\hline$e_{b}, \%$ & -6.14 & -3.37 & --- \\
\hline$\eta$ & 24.63 & 24.10 & 23.47 \\
\hline$e_{\eta}, \%$ & 4.94 & 2.68 & --- \\
\hline
\end{tabular}

(e) is computed using Eq. (19) for both quantities (b and $\eta$ ) with respect to the corresponding value obtained on the finest grid $(2.6 \mathrm{M}$ cells). The symbol $\otimes$ corresponds to the value obtained on the medium grid (2.1M cells) or coarse grid (1.2M cells), respectively.

$$
e_{\otimes}=\frac{\otimes-\otimes_{2.6 M}}{\otimes_{2.6 M}} \times 100[\%]
$$

The relative error $(e)$ values for both quantities $(b$ and $\eta$ ) and both grids (medium and coarse) are included in Table 2. The relative error values associated to the aerodynamic efficiency computed on both grids (coarse and medium) are less than $5 \%$. Therefore, the numerical results selected for validation against experimental data belong to the medium grid.

\section{CONCLUSION}

\section{ZAKLJUČAK}

The paper introduces a methodology developed to assess the aerodynamic performances of lumber drying kilns. The 3D computational domain corresponds to half of the drying kiln (by dividing the kiln along a symmetry plane at mid length) including a fan, two wood stacks and the airflow loop. The 3D turbulent computations are performed for five fan speeds considering air flow in both normal and reverse directions. A finite volume method (FVM) was used to solve the incompressible flow equations. The Reynolds stress model (RSM) was selected in order to capture the features of the turbulent flow associated with a drying kiln.

The experiment was carried out in a $4 \mathrm{~m}^{3}$ heatand-vent kiln loaded at maximum capacity, and five different fan speeds under reversible airflow conditions were tested. The numerical results obtained were validated against the experimental data that were measured in the drying kiln. A reasonable agreement was obtained between the numerical results and the experimental data in both airflow directions. 
Further, the methodology core was embedded in the integral quantities defined in the paper. This approach was taken in order to assess the aerodynamic performances of the drying kiln, by expressing the energy loss coefficient and the non-uniformity coefficient. The energy loss coefficient was determined based on the computed potential and kinetic energy coefficients. The value of the overall energy loss coefficient between the inlet and outlet section of the drying kiln in both airflow directions was determined to be about 2. However, the energy loss coefficient distribution along the drying kiln differed from one airflow direction to the other. A significant difference was observed in the reverse direction, which contains the stacks region; here the energy loss coefficient was no longer constant, but it decreased by approximately $10 \%$ due to the distribution of the kinetic energy component.

The non-uniformity coefficient is considered a good indicator for quantifying the flow distribution with respect to the ideal one. Larger values suggest greater flow non-uniformity. The non-uniformity coefficient distributions in both airflow directions reveal larger values in the fan house located in front of the inlet section. This is in good agreement with the numerical results.

Finally, the bypass coefficient and the aerodynamic efficiency were computed, in order to assess the aerodynamic performances of the drying kiln. The bypass coefficient revealed that the quantity of air that goes around the stacks is three times greater than the quantity of air that passes through the sticker spaces for the given configuration. As a result, very low aerodynamic efficiency values were yielded: $24 \%$ in the normal flow direction and $25 \%$ in the reverse direction, even with a full-loaded kiln. A detailed analysis of air leakage through each gap around the stacks revealed changes in the percentage of air loss through the top gap (from inlet to outlet section), namely, $7 \%$ and $24 \%$ in the normal and reverse airflow directions, respectively. In order to overcome the negative effects of the air bypass upon the drying time, energy consumption and drying uniformity, the drying kiln has to be equipped with baffles.

The methodology developed and validated in this paper can be further applied to assess the aerodynamic performance of lumber drying kilns with different configurations. Also, various solutions (e.g. baffles) to improve the airflow in lumber drying kilns could be simulated based on the quantities defined in this paper (e.g. energy loss coefficient, non-uniformity coefficient and bypass coefficient).

\section{Acknowledgment - Zahvala}

Dr. Bedelean B. was supported in this research by the Transilvania University of Brasov, Romania through a scholarship for research purposes. The equipment used in this research was purchased with a $\mathrm{PhD}$ CNCSIS grant, topic 318, funded by the National University Research Council (CNCSIS). Dr. Muntean S. was supported by the Romanian Academy program. The numerical computations were performed at the Research Center for Engineering with Complex Fluids from the Polytechnical University of Timisoara.

\section{REFERENCES}

\section{LITERATURA}

1. Arnaud, G.; Fohr, J. P., Garnier, J. P.; Ricolleau, G., 1991: Study of the air flow in a wood drier. Drying Technology, 9 (1): $183-200$

http://dx.doi.org/10.1080/07373939108916646.

2. Bedelean, B.; Sova, D., 2012: Performance assessment of a laboratory drying kiln designed with and without baffles. Pro Ligno, 8 (2): 89-99 http://dx.doi.org/10.1179/2042645310Y.0000000004.

3. Bedelean, I. B.; Sova, D., 2010: Investigations into possibility of minimising aerodynamic resistance of kiln drying stack. International Wood Product Journal, 1 (2): 63-69 http://dx.doi.org/10.1179/2042645310y.0000000004.

4. Bian, Z., 2001: Airflow and wood drying models for wood kiln. Master thesis, University of British Columbia.

5. Craft, T. J.; Gant, S. E.; Iacovides, H.; Lauder, B. E., 2004: A New Wall Function Strategy for Complex Turbulent Flows, Numerical Heat Transfer, Part B, 45: 301$318 \mathrm{http} / / / \mathrm{dx}$. doi.org/10.1080/10407790490277931.

6. Fernández Oro, J. M.; Ballesteros-Tajadura, R.; Blanco Marigorta, E.; Argüelles Diaz, K. M.; Santolaria Morros, C., 2008: Turbulence and Secondary Flows in an Axial Flow Fan With Variable Pitch Blades. ASME Journal of Fluids Engineering, 130 (4).

http://dx.doi.org/10.1115/1.2903523.

7. Fluent Inc. 2006a: Gambit 2.4 User's Guide. Lebanon, USA.

8. Fluent Inc. 2006: FLUENT 6.3 User's Guide. Lebanon, USA.

9. Hinze, J. O., 1975: Turbulence. Columbus, MacGraw-Hill.

10. Hua, L.; Bibeau, E.; He, P.; Gartshore, I.; Salcudean, M.; Bian, Z.; Chow, Z., 2001: Modeling of airflow in wood kilns. Forest Products Journal, 51 (6): 74-81.

11. Jamaleddine, T. J.; Ray, M. B., 2010: Application of Computational Fluid Dynamics for Simulation of Drying Processes: A Review. Drying Technology, 28 (2): 120154. http://dx.doi.org/10.1080/07373930903517458.

12. Karypis, G.; Kumar, V., 1998: METIS: A Software Package for Partitioning Unstructured Graphs, Partitioning Meshes, and Computing Fill - Reducing Ordering of Sparse Matrices. Technical Report Version 4.0, University of Minnesota, Department of Computer Science / Army HPC Research Center.

13. Keey, R. B.; Langrish, T. A. G.; Walker, J. C. F., 2000: Kiln-drying of lumber. Berlin, Springer-Verlag http://dx.doi.org/10.1007/978-3-642-59653-7.

14. Kim, S-E.; Choudhury, D., 1995: A Near-Wall Treatment Using Wall Functions Sensitized to Pressure Gradient. In: "Separated and Complex Flows", ASME FED 217.

15. Langrish, T. A. G.; Keey, R. B., 1996: The effects of air bypassing in lumber kilns on fan power consumption. In: Proceedings of CHEMECA, Sydney, Australia, September 30 - October 2, pp 103-108.

16. Ledig, S. F.; Paarhuis, B.; Riepen, M., 2007: Airflow within kilns. P. Perre (ed): Fundamentals of Wood Drying. Nancy, A.R.BO.LOR, pp. 291-332.

17. Ledig, S. F.; Nijdam, J. J.; Keey, R., 2001: Airflow distributions in the fillet spaces of a lumber stack. Drying Technology, 19 (8): 1697-1710. http://dx.doi.org/10.1081/drt-100107267.

18. Nijdam, J. J.; Keey, R. B., 1996: Influence of local variations of air velocity and flow direction reversals in the drying of stacked boards in kilns. TransICheme, 74 (A): 882-892. http://dx.doi.org/10.1205/026387696523184. 
19. Perot, B.; Natu, S., 2004: A model for the dissipation rate tensor in inhomogeneous and anisotropic turbulence. Physics of Fluids, 16 (11): 4053-4065. http://dx.doi.org/10.1063/1.1801392.

20. Perre, P.; Keey, R., 2006: Drying of wood: principles and practice. A.J. Mujumdar (Ed) Handbook of Industrial Drying, $3^{\text {rd }}$ edn. New York, Dekker, pp. $821-877$.

21. Riepen, M.; Paarhuis, B., 1999: Analysis and optimisation of the airflow distribution in convection kilns. In Proceedings of COST-E15 Workshop, Edinburgh.

22. Riley, S., 2006: Baffled about baffling! Why is it so important to baffle my drying stack. Wood Processing Newsletter, 38: 1-3.

23. Salin, J. G.; Ohman, G., 1998: Calculation of drying behaviour in different parts of lumber stack. In Proceedings of 11th International Drying Symposium, Halkidiky, Greece, August 19-22, Vol. B, pp. 1603-1610.

24. Sun, Z. F., 2001: Numerical simulation of flow in an array of in-line blunt boards: mass transfer and flow pat- terns. Chemical Engineering Science, 56 (5): 1883-1896. http://dx.doi.org/10.1016/s0009-2509(00)00464-4.

25. Susan-Resiga, R.; Muntean, S.; Hasmatuchi, V.; Anton, I.; Avellan, F., 2010. Analysis and prevention of vortex breakdown in the simplified discharge cone of a Francis turbine. ASME Journal of Fluids Engineering, 132(5). http://dx.doi.org/10.1115/1.4001486.

\section{Corresponding address:}

\section{BOGDAN BEDELEAN, Ph.D.}

Faculty of Wood Engineering

Transilvania University of Brasov

B-dul Eroilor nr.29

500036, Brasov, ROMANIA

e-mail: bedelean@unitbv.ro 